\title{
Effect of use Probiotics and Organic Fertilizer on Yield of Peanut on Tra Vinh Province, Vietnam
}

\author{
Nguyen Thi Lang, Le Hoang Phuong, Nguyen Thi Hong Loan, Le Minh Khang, NT \\ Khanh Tran, Bui Chi Hieu
}

High Agricultural Technology Research Institute for Mekong delta, Viet Nam

Received: 03 Oct 2021; Received in revised form: 09 Dec 2021; Accepted: 20 Dec 2021; Available online: 30 Dec 2021

C2021 The Author(s). Published by Infogain Publication. This is an open access article under the CC BY license

(https://creativecommons.org/licenses/by/4.0/).

\begin{abstract}
This study was to evaluate the effects, determine the appropriate, and assess the profitability of using locally produced organic foliar fertilizers on peanut production. The experiment was installed in CauNgang andTra $\mathrm{Cu}$ with two variety MD7, L14. Seven fertilizer treatments were designed.The treatments consisted of the application of T1:(Trichoderma sp + Bordeaux 1\% + Probiotics 3M; T2: (organic fertilizer $=10$ ton/ha);T 3: (Trichoderma $s p+$ Bordeaux $1 \%+$ Probiotics $3 M+$ chemical fertilizers $(35 \mathrm{~N}-60 \mathrm{P}-60 \mathrm{~K}+150 \mathrm{~kg} \mathrm{Ca}+40 \mathrm{~kg} \mathrm{Mg})+$ organic fertilizer 100\%) T4: (Trichoderma $\mathrm{sp}+$ Bordeaux $1 \%+$ Probiotics $3 M+$ chemical fertilizers $(35 \mathrm{~N}-60 \mathrm{P}-60 \mathrm{~K}+150 \mathrm{~kg} \mathrm{Ca}+40 \mathrm{~kg} \mathrm{Mg})+$ organic fertilizer $75 \% ; T 5($ Trichoderma sp + Bordeaux $1 \%+$ Probiotics $3 M+$ chemical fertilizers + organic fertilizer $50 \%) ;$ T6: chemical fertilizers $(35 \mathrm{~N}-60 \mathrm{P}-60 \mathrm{~K}+150 \mathrm{~kg} \mathrm{Ca}+40 \mathrm{~kg}$ $\mathrm{Mg})+($ Trichoderma $\mathrm{sp}+$ Bordeaux 1\% + Probiotics 3M)and T7 control and treatment of farmers: (120 $\mathrm{N}-60 \mathrm{P}-60 \mathrm{~K}+200 \mathrm{Ca} \mathrm{kg} / \mathrm{ha})$. The experimental design adopted consisted of randomized complete blocks with three replications. Results showed that peanut plants flowered early when applied with T3 (Trichodermasp + Bordeaux 1\% + CPVS 3M) + chemical fertilizer $+100 \%$ organic fertilizer) significantly increase plant height, number of branches/ plant, ability to absorb N. P. K. 100 seeds, weight of pods( $\mathrm{g} / \mathrm{plant}$ ) and seeds of plant. The increase/decrease in fertilizer intake had a significant and statistically significant effect $(p \leq 0.05)$ on peanut yield and quality in both treatments areas, with the exception of 100 grains. If only organic fertilizer is not combined with microbiological preparations, the manure of black spots and brown spots is higher than the experimental in combination with the treatment fertilizer combined with the balanced amount of fertilizer in the T5 treatments(Trichoderma sp + Bordeaux $1 \%+$ Probiotics $3 M+$ chemical fertilizers + organic fertilizer $50 \%)$.
\end{abstract}

Keywords-Peanut, Probiotics, nutritional status, N. P. K. yield, yield components.

\section{INTRODUCTION}

Peanuts (Arachishypogaea L.) are also named groundnuts, belonging to the family Leguminosae that produces underground fruits known as shell beans (Aboelill et al.. 2012). Growing peanuts helps enrich the soil's nutrients due to its ability to fix nitrogen in the atmosphere. Peanuts require only a small amount of $\mathrm{N}$ because of their ability to fix nitrogen from the atmosphere (Jordan et al., 2017). Organic matter can be used as fertilizer because it contains essential nutrients such as nitrogen, phosphorus, potassium, calcium, iron, manganese, zinc, copper, magnesium and proteins that stimulate the metabolism of plants. Organic fertilizers are an excellent alternative to in innocuous fertilizers in crops that require fewer nutrients for their growth and development. The use of organic leaf fertilizer is beneficial. It contains microorganisms such as bacteria that accelerate the mineralization of organic materials and help plants absorb quickly.The impact of agrochemical pollution in air, water and soil profoundly affects human health through the accumulation of toxins from living in a toxic environment and consuming toxic foods (Katherine 
and Hendrik. 2010). This effect will increase the rates of asthma,Autism, physical disabilities, learning disabilities, reproductive disorders, diabetes, Parkinson's disease. Alzheimer's disease and cancer (Owens et al.,2010). In addition to directly affecting human health, chemicals from agricultural activities also affect the ecosystems of plants and animals. Finally, humans are affected by the consumption of these products and meats (Onder et al., 2011; Sharma and Singhvi, 2017).

The use of chemical fertilizers, pesticides and pesticides has continued for a long time in the agricultural production process and is widely found in farm systems (Aktar et al., 2009; Savci. 2012), where health effects are found both in consumers and farmers using chemicals for agricultural activities (Costa et al., 2014). Accordingly, organic products are a new trend and a great opportunity for manufacturers in the food industry. (Ferella et al., 2019). Biodegradable can significantly reduce soil N2O emissions, stabilize soil organic $\mathrm{C}$, and the activity of microbial functional groups, especially debactericiologists (Yuan et al., 2017).

Chemical fertilizers have long been considered a necessary solution capable of replacing the natural fertility of the soil. Although they are effective, they are difficult to access, with many limitations such as being very expensive to buy, pollution and increasing the resistance of many pathogens to the commonly used dose of chemical fertilizers (Janny et al., 2003). For sustainable development, it is necessary to change behavior and innovate by proposing new ways to produce new cropping systems that are primarily based on natural processes to meet both food security needs and the need for more balanced management of natural resources. Many studies have focused on the biology of microorganisms that rapidly affect the rapid mineralization of organic matter
(Higa, 1996). Native microorganisms (IMO) and effective microorganisms (EM) form a source of nutrient reserves. Their role as a mineralize increases soil fertility, while making them less compacted and eroded (Narasimha et al., 2012). IMO consists of microorganisms consisting mainly of bacteria,fungi and yeast. EM is a commercial solution of effective microorganisms consisting mainly of bacteria and yeast (Helen et al., 2006). The goal of this study is to assess the impact of native microbial-based organic fertilizers on peanut yields in the coastal region of TraVinh. In addition, the goal is to analyze the chemical physical properties of the soil before and after the application of fertilizer to determine soil fertility, and to assess the impact of vaccination of these microorganisms on the growth and productivity of peanuts at TraVinh.

\section{MATERIAL AND METHODS}

\subsection{Varieties :MD7 and L14.}

\subsection{Experimental design and treatments}

-Experiment was conducted at $\mathrm{Tra} \mathrm{Cu}$ and CauNgangof TraVinh province, with sandy soil structures. Experimental soils have been growing peanuts for ten years and in recent years are managed in the conservation system for the peanut region. Prior to the experiment the soil layer was collected in each area in layers 0 to $30 \mathrm{~cm}$ deep to make up the composite sample, which was used to analyze chemical indicators according to the method of Raij et al., (2001) and particle size according to Camargo et al., (2009).

- The experiment was arranged on the farmer's field in a completely random mass (02 varieties, 7 treatments, 3 replications. at 02 locations. the area of plots is $25 \mathrm{~m} 2)$.

Table 1: Treatments of fertilizers used experiments

\begin{tabular}{|c|c|c|c|}
\hline no & Treatments & Contents & note \\
\hline 1 & $\mathrm{~T} 1$ & (Trichoderma sp + Bordeaux 1\% + Probiotics 3M) & \multirow{4}{*}{$\begin{array}{l}\text { (fermented } \\
\text { cow manure) }\end{array}$} \\
\hline 2 & $\mathrm{~T} 2$ & organic fertilizer $=10$ ton $/ \mathrm{ha}$ & \\
\hline 3 & $\mathrm{~T} 3$ & $\begin{array}{l}\text { Trichoderma sp + Bordeaux 1\%+ Probiotics 3M) + chemical fertilizers }(35-60-60+ \\
150 \mathrm{~kg} \mathrm{Ca}+40 \mathrm{~kg} \mathrm{Mg})+ \text { organic fertilizer } 100 \%\end{array}$ & \\
\hline 4 & T4 & $\begin{array}{l}\text { Probiotics (Trichoderma sp + Bordeaux 1\%+ Probiotics 3M) + chemical } \\
\text { fertilizers }(35-60-60+150 \mathrm{~kg} \mathrm{Ca}+40 \mathrm{~kg} \mathrm{Mg})+\text { organic fertilizer75\% }\end{array}$ & \\
\hline 5 & T5 & $\begin{array}{l}(\text { Trichoderma sp }+ \text { Bordeaux } 1 \%+\text { Probiotics } 3 \mathrm{M})+\text { chemical fertilizers }(35-60-60+ \\
150 \mathrm{~kg} \mathrm{Ca}+40 \mathrm{~kg} \mathrm{Mg})+ \text { organic fertilizer } 50 \%\end{array}$ & \\
\hline 6 & T6 & $\begin{array}{l}\text { Chemical fertilizers }(35-60-60+150 \mathrm{~kg} \mathrm{Ca}+40 \mathrm{~kg} \mathrm{Mg})+(\text { Trichoderma sp + } \\
\text { Bordeaux } 1 \%+\text { Probiotics 3M) }\end{array}$ & \\
\hline 7 & $\mathrm{~T} 7$ & fellowing farmers $(120-60-60+200 \mathrm{Ca} \mathrm{kg}) .($ control $)$ & \\
\hline
\end{tabular}


The process of planting and caring techniques (land preparation. planting density. care. harvesting) is carried out in accordance with Guidance No. 52/HD-SNN.

\subsection{Data collection}

Plant height: is determined by a ruler $\mathrm{cm}$ at the end of the harvest cycle (90 days) from the surface of the soil to the end of the main of 10 trees in each plot of experiment.
Number of leaves and number of branches: calculated at the end of the harvest period, using samples of 10 plants per experiment. Factors that constitute yield and yield components : The number of pods per plant, the number of seeds per plant is determined by counting the bark and seeds of the 10 plants selected from each experiment. 100 seeds weight $(\mathrm{g})$ : Weighs 100 seeds in each treatment weight of pods ( g/ plant);Seed yield( gram) : The seeds obtained from each plot were weighed using weighing scale.Number of nodules : were counted.

Disease assessment

Table 2: Disease level assessment scale of iron and brown spots (Subrahmanyam et al. 1997)

\begin{tabular}{|c|c|c|c|}
\hline Rust disease & $\begin{array}{c}\% \\
\text { infected }\end{array}$ & scale & Early leaf spot and late lateleaf spot \\
\hline No traces of disease. & 0 & 1 & No traces of disease. \\
\hline There are a few small dots on the old leaves. & $1-5$ & 2 & There are a few small spots on the old leaves. \\
\hline $\begin{array}{l}\text { A few small spots on the leaves are old and } \\
\text { have the formation of spores like dust particles }\end{array}$ & $6-10$ & 3 & $\begin{array}{l}\text { Appears a few spots mainly on old leaves. } \\
\text { there is weak spore formation }\end{array}$ \\
\hline $\begin{array}{l}\text { Many small spots are largely on young leaves } \\
\text { and are located in the leaves themselves. the } \\
\text { formation of spores }\end{array}$ & $11-20$ & 4 & $\begin{array}{l}\text { Many spots have small or large vows, most of } \\
\text { which occur in the lower leaves low and the } \\
\text { leaves in the middle, the stain appears clearly. }\end{array}$ \\
\hline $\begin{array}{l}\text { Small spots are easily visible in the lower } \\
\text { leaves and the middle leaves of the plant have a } \\
\text { mild spore formation. }\end{array}$ & $21-30$ & 5 & $\begin{array}{l}\text { Many pustules, mostly on lower and middle } \\
\text { leaves yellowing and necrosis of some lower } \\
\text { and middle leaves. moderately sporulating }\end{array}$ \\
\hline $\begin{array}{l}\text { It's like a } 5 \text { score -grade illness, but there are } \\
\text { more spots. }\end{array}$ & $31-40$ & 6 & The same with score but there are more spots \\
\hline $\begin{array}{l}\text { spotsappear most of the trees. there is necrosis } \\
\text { in the low leaves and the middle leaves }\end{array}$ & $41-60$ & 7 & $\begin{array}{l}\text { Spots are easily visible at long distances, dots } \\
\text { are present almost all over the leaves, there is } \\
\text { deciduousness in the low leaves and the } \\
\text { middle leaves. }\end{array}$ \\
\hline $\begin{array}{l}\text { The level of the disease is level } 7, \text { but the level } \\
\text { of necrosis is more severe. }\end{array}$ & $61-80$ & 8 & $\begin{array}{l}\text { The level of the disease is level } 7 \text {, but the } \\
\text { level of necrosis is more severe }\end{array}$ \\
\hline $50-100 \%$ The leaves on the plant are fallen. & $81-100$ & 9 & $50-100 \%$ The leaves on the plant are fallen \\
\hline
\end{tabular}

\subsection{Statistical analysis}

All the data obtained was analyzed method by procedure in SAS (Version 9.4, SAS Institute Inc., 2017). The difference has the slightest meaning (LSD) at $5 \%$ to compare the differences between the tests.

\section{RESULTS AND DISCUSSION}

\subsection{Experimental soil propertie}

In the condition that the land of peanuts has been arranged to grow peanuts for 1 crop with innocuous fertilizer levels. Soil analysis results at Tra $\mathrm{Cu}$ and
CauNgang locations showed that the soil protein parameters were $1.04 \%$ at $\mathrm{Tra} \mathrm{Cu}$ and theCauNgangpoint was $0.95 \%$. Organic $\mathrm{C}$ levels were not high $(0.92 \%$ and $0.86 \%$ ) (Tran et al., 2021) to 1.04 ( Tra $\mathrm{Cu}$ score to 0.95 (at CauNgang) at this experiment after planting a peanut experiment. (Table 3). Total protein also increased from 0.87- $0.93 \%$ for Tra $\mathrm{Cu}$ and CauNganginrespecity. Mild sour soil - neutral ( $\mathrm{pH}, \mathrm{KCl} 6.1-6.5)$. Peanuts grow best in slightly acidic soil with 6.0 to 6.5 . 
Table 3: Some properties of the tested soil ( $0-30 \mathrm{~cm}$ depth) after harvested one season

\begin{tabular}{|l|l|l|}
\hline Property & Tra Cu & CauNgang \\
\hline \% Nitrogen & 0.87 & 0.93 \\
\hline$\%$ Potassium & 150.2 & 128.4 \\
\hline$\%$ Sodium & 71.6 & 83.5 \\
\hline$\%$ Magnesium & 97.2 & 110.3 \\
\hline \% Calcium & 241 & 380.33 \\
\hline$\%$ Manganese & 95.7 & 112.6 \\
\hline$\%$ Zinc & 2.56 & 3.56 \\
\hline$\%$ Cooper & 3.68 & 2.03 \\
\hline$\%$ Iron & 79.5 & 108.8 \\
\hline$\%$ Organic & 1.04 & 0.95 \\
\hline pH & 6.1 & 6.5 \\
\hline$\%$ Sand & 58.36 & 65.78 \\
\hline$\%$ Silt & 31.5 & 40.20 \\
\hline$\%$ Clay & 1.20 & 2.02 \\
\hline
\end{tabular}

3.2. Effects of fertilizers on peanut growth, development and productivity

3.2.1. Analysis of the impact of fertilizers on tree growth .This analysis is based on three traits: plant height, number of branches on the plant and number of leaves on the plant in two different locations.

\section{a) Experiment at $\operatorname{Tra~} \mathrm{Cu}$}

The height of fluctuating plant is statistically significant. The average height of the MD7 is $60.2 \mathrm{~cm}$ in the T2 treatments (organic fertilizer) only. The tallest height in the T3 treatment is $(65.8 \mathrm{~cm})$. The average heighplant of L14 when not fertilized is $52.6 \mathrm{~cm}$ in the T1 treatment and the highest is also in the full fertilization treatment (T3) fully fertilized microbiological, organic and chemical fertilizer $(58.3 \mathrm{~cm})$. For the number of branches/ plant, the L14 and M D7 varieties both give the number of branches on the plant in the T3 treatment. The number of leaves is affected by varieties. The average number of leaves of the MD7 is lower than that of the L14. The MD7 has the highest number of leaves in the T3 treatment (79.4) and the lowest of 67.8 (T7). While the L14 has the lowest average value of 81.6 (T2 treatment) to 93.4 leaves in the T3 treatment.

\section{b) Experiment at CauNgang}

Similar to the experiment at $\operatorname{Tra} \mathrm{Cu}$, at CauNgang the average height plant of the MD7 is $60.2 \mathrm{~cm}$ in the T2 (organic fertilizationonly ). The height is highest in the $\mathrm{T} 3$ treatment $(65.8 \mathrm{~cm})$. For the L14 the lowest height plant is also in the T1 treatment and the tallest in the F7 test is $52.6 \mathrm{~cm}, 59.6 \mathrm{~cm}$ respectively. For the number of branches/ plant, the L14 and MD7 varieties give a range of 9.2 to 11.7 for L14 and the number of branches on the plant the MD7 variety is 8.4 to 11.5 respectively. The number of leaves/ plant of the L14 variety is also higher than that of MD7,treatments are statistically different (table 4).

Table 4.Effects of fertilizers on peanut growth, development and productivity

\begin{tabular}{|c|c|c|c|c|c|c|}
\hline \multirow[t]{2}{*}{ Treatments(T) } & \multicolumn{3}{|c|}{ MD7 } & \multicolumn{3}{|c|}{ L14 } \\
\hline & $\begin{array}{l}\text { Height Plant } \\
(\mathrm{cm})\end{array}$ & $\begin{array}{c}\text { number of } \\
\text { branches } \\
\text { /plant }\end{array}$ & $\begin{array}{c}\text { number of } \\
\text { leaves } \\
\text { /plant }\end{array}$ & $\begin{array}{l}\text { Height Plant } \\
(\mathrm{cm})\end{array}$ & $\begin{array}{c}\text { number of } \\
\text { branches } \\
\text { /plant }\end{array}$ & $\begin{array}{c}\text { number of } \\
\text { leaves/ plant }\end{array}$ \\
\hline \multicolumn{7}{|c|}{ Site 1: Tra $\mathrm{Cu}$} \\
\hline $\mathrm{T} 1$ & $62.3 \mathrm{~d}$ & $10.5 b$ & $79.3 a$ & $52.6 \mathrm{e}$ & $10.3 \mathrm{~b}$ & $92.3 b$ \\
\hline $\mathrm{T} 2$ & $60.2 \mathrm{e}$ & $10.2 b$ & $75.2 \mathrm{c}$ & $56.4 \mathrm{c}$ & $9.2 \mathrm{c}$ & $81.6 \mathrm{e}$ \\
\hline T3 & $65.8 \mathrm{a}$ & $11.5 \mathrm{a}$ & $79.4 a$ & $58.3 a$ & $11.7 \mathrm{a}$ & $93.4 a$ \\
\hline $\mathrm{T} 4$ & $63.1 \mathrm{c}$ & $10.7 b$ & $78.5 b$ & $57.2 b$ & $11.1 \mathrm{a}$ & $90.8 \mathrm{c}$ \\
\hline T5 & $61.4 \mathrm{~d}$ & $9.5 \mathrm{c}$ & $78.4 \mathrm{~b}$ & $55.8 \mathrm{~d}$ & $10.8 \mathrm{~b}$ & $90.1 \mathrm{c}$ \\
\hline T6 & $64.5 b$ & $9.7 \mathrm{c}$ & $73.2 \mathrm{~d}$ & $55.3 \mathrm{~d}$ & $10 \mathrm{~b}$ & $89.6 \mathrm{~d}$ \\
\hline T7 & $61.7 \mathrm{~d}$ & $8.4 \mathrm{e}$ & $67.8 \mathrm{e}$ & $56.5 c$ & $10.4 b$ & $90.4 \mathrm{c}$ \\
\hline \multicolumn{7}{|c|}{ Site 2: CauNgang } \\
\hline $\mathrm{T} 1$ & $62.4 \mathrm{~d}$ & $9.0 \mathrm{c}$ & $76.1 \mathrm{~b}$ & $56.3 d$ & $10.8 \mathrm{~b}$ & $93.3 b$ \\
\hline $\mathrm{T} 2$ & $57.2 \mathrm{f}$ & $8.0 \mathrm{~d}$ & $68.2 d$ & $52.2 \mathrm{e}$ & $8.3 \mathrm{c}$ & $82.4 \mathrm{f}$ \\
\hline
\end{tabular}




\begin{tabular}{|c|c|c|c|c|c|c|}
\hline T3 & $65.2 \mathrm{a}$ & $11.0 \mathrm{a}$ & $78.5 \mathrm{a}$ & $59.5 \mathrm{a}$ & $11.8 \mathrm{a}$ & $94.8 \mathrm{a}$ \\
\hline T4 & $64.3 \mathrm{~b}$ & $10.4 \mathrm{~b}$ & $76.3 \mathrm{~b}$ & $58.4 \mathrm{~b}$ & $11.2 \mathrm{a}$ & $92.6 \mathrm{c}$ \\
\hline T5 & $63.3 \mathrm{c}$ & $10.0 \mathrm{~b}$ & $75.6 \mathrm{c}$ & $57.3 \mathrm{c}$ & $10.6 \mathrm{~b}$ & $91.6 \mathrm{~d}$ \\
\hline T6 & $61.7 \mathrm{e}$ & $9.0 \mathrm{c}$ & $78.2 \mathrm{a}$ & $56.1 \mathrm{~d}$ & $10.6 \mathrm{~b}$ & $90.5 \mathrm{e}$ \\
\hline T7 & $62.8 \mathrm{~d}$ & $10.0 \mathrm{~b}$ & $76.2 \mathrm{~b}$ & $59.6 \mathrm{a}$ & $11.0 \mathrm{a}$ & $91.4 \mathrm{~d}$ \\
\hline
\end{tabular}

3.2.2. Effects of fertilizers on peanut yield and component yield

\section{a) Experiment at Tra $\mathrm{Cu}$}

There were considerable differences in the mean number of pods per plant among the different plant of treatments. The treatment with a population of five plants per pot produced a mean number of 14.3-17.9 pods per plant for MD7. On average, the number of pods per plant affected by the variety and the proportion and dosage of adequate fertilizer according to the treatment (T3); the average number of seeds/ plant is significantly higher for both MD7 and L14 varieties at 17.8 and 18.6 inrespectively. This recorded the number of seeds on the T3 treatment for the higher number of particles on the
MD7 and L14 varieties. Most of both the number of pod /plant and the number of seeds on plant are statistically significant. Except for the average volume of 100 seeds weight that are no different on fertilizer treatments.

\section{b) Experiment at CauNgang}

The experiment at CauNgangrecorded the number of pods perplant, the number of seeds on the plant of the two varieties MD7 and L14 are both statistically significant differences of the MD7 variety. The highest number of podsperplant is the $\mathrm{T} 3$ and $\mathrm{T} 4$ treatments, on the two varieties MD 7 and L14. The Hundred seed weight is also an important yield component which reflects the magnitude of seed development which ultimately reflects on the final yield of a crop. (Table 5)

Table.5. Effects of fertilizers on peanut component yield

\begin{tabular}{|c|c|c|c|c|c|c|}
\hline \multirow[t]{2}{*}{ Treatment(T) } & \multicolumn{3}{|c|}{ MD7 } & \multicolumn{3}{|c|}{ L14 } \\
\hline & $\begin{array}{l}\text { Number of } \\
\text { pods per } \\
\text { plant }\end{array}$ & $\begin{array}{ll}\text { seeds } & \text { per } \\
\text { plant } & \end{array}$ & $\begin{array}{l}100 \text { seed weight } \\
\text { (g) }\end{array}$ & $\begin{array}{l}\text { Number of } \\
\text { pods per } \\
\text { plant }\end{array}$ & $\begin{array}{c}\text { seeds per } \\
\text { plant }\end{array}$ & $\begin{array}{l}100 \text { seed weight } \\
(\mathrm{g})\end{array}$ \\
\hline \multicolumn{7}{|c|}{ Site 1: $\mathrm{Tra} \mathrm{Cu}$} \\
\hline $\mathrm{T} 1$ & $16.8 \mathrm{~b}$ & $30.7 \mathrm{e}$ & $44.5 \mathrm{a}$ & $17.2 \mathrm{~b}$ & $25.5 \mathrm{a}$ & $35.3 \mathrm{a}$ \\
\hline $\mathrm{T} 2$ & $14.3 \mathrm{~d}$ & $25.3 \mathrm{f}$ & $44.1 \mathrm{~b}$ & $13.1 \mathrm{~d}$ & $19.8 \mathrm{e}$ & $34.9 \mathrm{a}$ \\
\hline T3 & $17.9 \mathrm{a}$ & $35.8 \mathrm{a}$ & $45.7 \mathrm{a}$ & $18.6 \mathrm{a}$ & $25.7 \mathrm{a}$ & $35.3 \mathrm{a}$ \\
\hline T4 & $17.5 \mathrm{a}$ & $34.2 \mathrm{~b}$ & $45.2 \mathrm{a}$ & $18.1 \mathrm{a}$ & $25.1 \mathrm{a}$ & $35.6 \mathrm{a}$ \\
\hline T5 & $16.6 \mathrm{~b}$ & $33.3 \mathrm{c}$ & $45.6 \mathrm{a}$ & $17.6 \mathrm{~b}$ & $24.9 \mathrm{~b}$ & $35.4 \mathrm{a}$ \\
\hline T6 & $15.4 \mathrm{c}$ & $32.6 \mathrm{~d}$ & $45.5 \mathrm{a}$ & $16.6 \mathrm{c}$ & $20.2 d$ & $35.6 \mathrm{a}$ \\
\hline T7 & $14.9 \mathrm{~d}$ & $30.6 \mathrm{e}$ & $45.5 \mathrm{a}$ & $16.7 \mathrm{c}$ & $22.6 \mathrm{c}$ & $35.3 \mathrm{a}$ \\
\hline \multicolumn{7}{|c|}{ Site 2: CauNgang } \\
\hline T1 & $19.2 \mathrm{a}$ & $40.3 a$ & $44.9 \mathrm{a}$ & $18.7 \mathrm{~b}$ & $30.3 \mathrm{c}$ & 39.6a \\
\hline $\mathrm{T} 2$ & $17.5 \mathrm{c}$ & $30.2 \mathrm{~d}$ & $44.5 \mathrm{a}$ & $15.8 \mathrm{~d}$ & $23.1 \mathrm{~d}$ & $38.3 b$ \\
\hline T3 & $19.7 \mathrm{a}$ & 40.6a & $44.8 \mathrm{a}$ & $19.5 \mathrm{a}$ & $32.9 \mathrm{a}$ & $39.7 \mathrm{a}$ \\
\hline T4 & $18.5 b$ & $40.5 \mathrm{a}$ & $44.2 \mathrm{a}$ & 19.2a & $32.7 \mathrm{a}$ & 39.6a \\
\hline T5 & $17.6 \mathrm{c}$ & $37.9 \mathrm{~b}$ & $44.3 \mathrm{a}$ & $18.9 \mathrm{~b}$ & $31.8 \mathrm{~b}$ & $39.1 \mathrm{a}$ \\
\hline T6 & $17.4 \mathrm{c}$ & $34.2 \mathrm{c}$ & $44.7 \mathrm{a}$ & $17.5 \mathrm{c}$ & $30.4 \mathrm{c}$ & $39.5 \mathrm{a}$ \\
\hline $\mathrm{T} 7$ & $17.6 \mathrm{c}$ & $37.5 b$ & $44.3 \mathrm{a}$ & $17.7 \mathrm{c}$ & $32.7 \mathrm{a}$ & 39.2a \\
\hline
\end{tabular}




\subsubsection{Effects of fertilizers on yield of peanut}

\section{a) Experiment at $\mathrm{Tra} \mathrm{Cu}$}

Nodule number was significantly $(\mathrm{P}<0.01)$ influenced due to the main effects of peanut cultivars and application fertilizers. The average number of nodules is also affected by the variety and proportion, dosage of nitrogen fertilizers. In the Probiotics (Trichoderma $\mathrm{sp}+$ Bordeaux $1 \%+$ Probiotics $3 \mathrm{M})+$ chemical fertilizers(35$60-60+150 \mathrm{~kg} \mathrm{Ca}+40 \mathrm{~kg} \mathrm{Mg})+$ organic fertilizer $100 \%$ ) (T3) the average number of nodules calculated for MD7 (46.5) is significantly different from the treatments(table 4). For the L14 in the T7,T3 and T4 tests the highest number of nodules is $43.9 ; 42.7 ; 41.3$ in respectively. Weight of pods(g/ plant)obtained on the plant on the MD7 variety is (29.3) highest in T3. Reducing the amount of fertilizer, the weight of pods(g/ plant)also decreased by 24.9 grams per plant on the T2 treatment. The yield of seeds on the MD7 variety is higher than L14 in the tests and is significant compared to the fertilization and non-fertilization test (table 4). At T1 treatment, the average weight of pods(g/ plant) is significantly different from the T2 and T7 treatment,seed yield is affected by the varieties, high productivity remains in $\mathrm{T} 1$, next to $\mathrm{T} 4$ and
T5. The lowest particle yield in the non-fertilization treatment (T7) for the MD7 variety. (Table 6)

\section{b) Experiment at CauNgang}

The average number of nodules calculated at the ratios and dosage of nitrogen fertilizers varies significantly. T3 treatments has the highest nodules(46.2), then T1( 46.1) on the MD7. For the L14 variety, the highest number of nodules/ plant in thefollowed by T1, T3 and T5 treatments (fluctuations from 43.2. 43.1 and 43.1 in respectively). Weight of pods(g/ plant)was significantly $(\mathrm{P}<0.01)$ affected by the interaction effect .The yield of seeds on the MD7 variety is higher than L14 in both treatments and is significant compared to the fertilization and non-fertilization treatments (table 6). At T1 the highest weight of pods(g/ plant)(28.9 g/plant), then T3 (28.4 g / plant). While the weight of pods (g/ plant) is lowest in the non-fertilization treatments (20.7 g/ plant) at L14 variety. Seed yield is affected by the variety, with high yields remaining in T1 (16.4 g/plant), then T3 (15.4 g/plant) and T8 (15.2 g/ plant) for the MD7 variety. For the L14 variety the most yielding in $\mathrm{T} 1$ (17.6 g/ plant), then T6 (16.9 g / plant). On the L14 at CauNgangrecorded in the treatment (T2) the yield of the grain has decreased,this is the same with Tra $\mathrm{Cu}$.

Table.6. Effects of fertilizers on yield of peanut

\begin{tabular}{|c|c|c|c|c|c|c|}
\hline \multirow[t]{2}{*}{ Treatment(T) } & \multicolumn{3}{|c|}{ MD7 } & \multicolumn{3}{|c|}{ L14 } \\
\hline & $\begin{array}{c}\text { number of } \\
\text { nodules/ } \\
\text { plant }\end{array}$ & $\begin{array}{c}\text { weight of } \\
\text { pods( g/ } \\
\text { plant) }\end{array}$ & $\begin{array}{l}\text { Seed yield (g/ } \\
\text { plant ) }\end{array}$ & $\begin{array}{c}\text { number of } \\
\text { nodules/ plant }\end{array}$ & $\begin{array}{l}\text { weight of } \\
\text { pods(g/ } \\
\text { plant) }\end{array}$ & $\begin{array}{l}\text { Seed yield (g/ } \\
\text { plant ) }\end{array}$ \\
\hline \multicolumn{7}{|c|}{ site1: Tra $\mathrm{Cu}$} \\
\hline $\mathrm{T} 1$ & $40.1 \mathrm{c}$ & $28.3 b$ & $18.8 \mathrm{a}$ & $39.5 \mathrm{e}$ & $23.2 \mathrm{~d}$ & $15.5 \mathrm{~d}$ \\
\hline $\mathrm{T} 2$ & $37.6 \mathrm{~d}$ & $24.9 \mathrm{~d}$ & $10.7 \mathrm{e}$ & $41.6 \mathrm{c}$ & $20.7 \mathrm{e}$ & $11.5 \mathrm{f}$ \\
\hline $\mathrm{T} 3$ & $46.8 \mathrm{a}$ & $29.3 a$ & $18.7 \mathrm{a}$ & $42.7 b$ & $26.5 a$ & $18.4 \mathrm{a}$ \\
\hline $\mathrm{T} 4$ & $45.3 b$ & $28.8 b$ & $18.1 \mathrm{a}$ & $41.3 c$ & $25.2 b$ & $17.1 \mathrm{~b}$ \\
\hline T5 & $44.2 b$ & $27.1 \mathrm{c}$ & $17.5 b$ & $40.8 \mathrm{~d}$ & $24.5 c$ & $16.6 c$ \\
\hline T6 & $44.1 b$ & $25.2 d$ & $16.3 \mathrm{c}$ & $39.2 \mathrm{e}$ & $23.8 \mathrm{~d}$ & $15.5 \mathrm{~d}$ \\
\hline $\mathrm{T} 7$ & $40.8 \mathrm{c}$ & $25.6 \mathrm{~d}$ & $15.2 \mathrm{~d}$ & $43.9 a$ & $20.9 \mathrm{e}$ & $14.4 \mathrm{e}$ \\
\hline \multicolumn{7}{|c|}{ Site 2: CauNgang } \\
\hline $\mathrm{T} 1$ & $46.2 \mathrm{a}$ & $31.9 \mathrm{a}$ & $18.3 \mathrm{a}$ & $43.2 \mathrm{a}$ & $23.5 c$ & $16.6 \mathrm{~b}$ \\
\hline $\mathrm{T} 2$ & $41.4 \mathrm{e}$ & $25.2 \mathrm{f}$ & $16.7 \mathrm{c}$ & $40.3 \mathrm{~d}$ & $20.4 \mathrm{f}$ & $10.3 d$ \\
\hline T3 & $46.3 \mathrm{a}$ & $29.3 b$ & $18.8 \mathrm{a}$ & $43.2 \mathrm{a}$ & $25.3 \mathrm{a}$ & $17.9 \mathrm{a}$ \\
\hline $\mathrm{T} 4$ & $45.6 b$ & $28.5 \mathrm{c}$ & $18.2 \mathrm{a}$ & $43.1 \mathrm{a}$ & $24.9 \mathrm{~b}$ & $17.5 \mathrm{a}$ \\
\hline T5 & $44.3 c$ & $28.2 \mathrm{c}$ & $17.5 b$ & $42.6 b$ & $23.1 \mathrm{c}$ & $16.9 \mathrm{~b}$ \\
\hline T6 & $43.2 \mathrm{~d}$ & $26.7 d$ & $17.6 \mathrm{~b}$ & $41.7 \mathrm{c}$ & $22.2 \mathrm{e}$ & $15.8 \mathrm{c}$ \\
\hline $\mathrm{T} 7$ & $43.8 \mathrm{~d}$ & $28.7 \mathrm{c}$ & $16.5 \mathrm{c}$ & $38.1 \mathrm{f}$ & $23.7 \mathrm{c}$ & $15.6 \mathrm{c}$ \\
\hline
\end{tabular}




\subsection{Effects of fertilizers on rust disease}

\subsubsection{Rust disease}

Rust disease is an economically important biotic stress that significantly reduces the pod and fodder yield and oil quality. It is caused by the basidiomycete fungus. Such as :Rust disease (Pucciniaarachidis),Brown spots (Cercosporaarachidicola), Black spots (phaeoisariopsispersonala).

Rust disease only occurs at the end of the growth and development of peanut plants. In the early stages, it is usually less common and the disease develops very strongly in the final stages. The varieties of peanut participating in the experiment suffered from rust disease from 1-3 score at this stage of 60 after sowing.
Brown spot disease and dark spot disease appear earlier than rust disease pediculosis from the time the peanut begin to flower causing severe harm at a 90-day period of 1-5 points for black spots on the $\mathrm{T} 7$ at CauNgang. Brown and black spots appear high in $\mathrm{T} 2$ on both CauNgangand Tra Cu.Cercosporaarachidicola is a fungal ascomycete plant pathogen that causes early leaf spot of peanut. All cultivars of peanuts are equally susceptible to peanut fungal pathogens; The results of this study indicated that genotypes MD 7 and L 14 were consistently tolerant under field conditions at $\mathrm{TraCu}$ and CauNgang with rust disease .

Table 7. Affected Rust disease.Earlyleaf spot ( brown spot)of peanut and late leaf spot ( (black spot)of peanut

\begin{tabular}{|c|c|c|c|c|c|c|}
\hline \multirow[t]{2}{*}{ Treatment $(\mathrm{T})$} & \multicolumn{3}{|c|}{ MD7 } & \multicolumn{3}{|c|}{ L14 } \\
\hline & Rust disease & $\begin{array}{c}\text { Early leaf } \\
\text { spot }\end{array}$ & late leaf spot & Rust disease & $\begin{array}{c}\text { Early leaf } \\
\text { spot }\end{array}$ & late leaf spot \\
\hline \multicolumn{7}{|c|}{ Site 1: $\operatorname{Tra} \mathrm{Cu}$} \\
\hline $\mathrm{T} 1$ & $\mathbf{0}$ & 2 & 2 & $\mathbf{0}$ & 2 & 2 \\
\hline $\mathrm{T} 2$ & 3 & 1 & 5 & 3 & 5 & 5 \\
\hline T3 & $\mathbf{0}$ & 1 & 1 & $\mathbf{0}$ & 1 & 1 \\
\hline $\mathrm{T} 4$ & $\mathbf{0}$ & $\mathbf{0}$ & 1 & $\mathbf{0}$ & $\mathbf{1}$ & 1 \\
\hline T5 & $\mathbf{0}$ & $\mathbf{0}$ & $\mathbf{0}$ & $\mathbf{0}$ & $\mathbf{0}$ & $\mathbf{0}$ \\
\hline T6 & $\mathbf{0}$ & 2 & 2 & $\mathbf{0}$ & 2 & 2 \\
\hline $\mathrm{T} 7$ & $\mathbf{0}$ & 2 & 3 & $\mathbf{0}$ & 3 & 1 \\
\hline \multicolumn{7}{|c|}{ Site2: CauNgang } \\
\hline T1 & $\mathbf{0}$ & 2 & 2 & $\mathbf{0}$ & 2 & 2 \\
\hline $\mathrm{T} 2$ & 1 & 3 & 3 & $\mathbf{0}$ & 5 & 3 \\
\hline T3 & $\mathbf{0}$ & 1 & 1 & $\mathbf{0}$ & 1 & 1 \\
\hline $\mathrm{T} 4$ & $\mathbf{0}$ & 1 & 1 & $\mathbf{0}$ & 1 & 1 \\
\hline T5 & $\mathbf{0}$ & 3 & 3 & $\mathbf{0}$ & 1 & 3 \\
\hline T6 & $\mathbf{0}$ & 2 & 2 & 1 & 3 & 3 \\
\hline $\mathrm{T} 7$ & $\mathbf{0}$ & 3 & 5 & $\mathbf{0}$ & 3 & 3 \\
\hline
\end{tabular}

\subsection{Discussion}

These yields trend also to explain that liming alone cannot serve to achieve the maximum potential of an acid soil, thus suggesting that the soils are more depleted of $\mathrm{N}$ and $\mathrm{K}$, which clearly influence crop performance as, was observed when these amendments (lime and $\mathrm{P}$ fertilizer) were applied in combination with manure (Farag and Zahran, 2014). Organic sources such as farm yard manure, ice husk ash, paper factory sludge along with chemical fertilizers improved the yield and quality of peanut kernels in a better and comparable way than lime (Basu et al., 2007). Table 4 shows that the agrocological properties of peanuts are affected by the application of different types of organic fertilizers. The methodical analysis shows that the heigh of plant, number of leaves varies significantly. Peanuts are treated with compost that flowers later than chemical fertilizers. According to (Jordan et al. (2017). Organic Fertilizers (Cow Manure. 
Chicken) provide a higher amount of $\mathrm{N}$ nutrients that enhance the early flowering of peanut plants. Lalog, (2011) mentioned that a certified organic leaf fertilizer is rich in very good macronutrients. Yield and yield components indicators of peanuts are affected by the application of various organic fertilizers presented in Table 5. The methodological analysis shows that the weight $(\mathrm{g})$ of 100 seeds, the weight of pods, and the seed yield (ton/ha-1) differ significantly between processing plants. Further explains that the power develops by increasing photosynthetic activity in the leaves, stimulating the need for water with leaves. Therefore, there is an increase in water absorption of the circuit system, which increases the quantity and quality of crop yields. On the other hand, the application of organic fertilizers as wet soil in combination with beneficial and effective microorganisms can be used instead of inorganic fertilizers. Likewise,tricoderma fungi improve the metabolism of plants and contribute to higher plant and yield production. It also enhances photosynthesis and increases the numbers of leaves of plants. Therefore, it increases the yield of crops (Mungkunkamchao. et al., 2013).

\section{Incidence of Insect Pest and Diseases to Peanut}

The rate of pests and diseases for peanuts. The rate of insect pests for peanut plants is presented in Table 7. The treatments shows high resistance to insect pests and resistance to levels 1-3 leaf spotting diseases. They produce reasonably higher productivity in all batches of experiments. Moreover, based on the reaction of the peanut plant (MD7 and L14 variety) to harmful insects and diseases, the variety is recommended for farmers because it is highly resistant to pests to medium. In fact, they can minimize the cost of pesticides. These results confirm the statement of (Brandenburg. et al., 2019).it is important to test the resistance of the varieties to pests before recommending it to farmers.

\section{CONCLUSION}

Treatment (Trichodermasp + Bordeaux $1 \%+$ Probiotics $3 \mathrm{M})+$ chemical fertilizer $+100 \%$ organic fertilizer) significantly increase plant height, number of branches/ plant, ability to absorb N. P. K. 100 seeds weight,weight of pods(g/ plant)and seeds yield. The increase/decrease in fertilizer intake had a significant and statistically significant effect $(\mathrm{p} \leq 0.05)$ on peanut weight of pods $(\mathrm{g} /$ plant $)$; seed of yield and quality in both treatmentsareas, with the exception of 100 grains. If only organic fertilizer is not combined with microbiological preparations, the manure of black spots and brown spots is higher than the experimental in combination with the treatment fertilizer combined with the balanced amount of fertilizer in the T5treatments(Trichodermasp + Bordeaux $1 \%+$ Probiotics $3 \mathrm{M})+$ chemical fertilizer $+50 \%$ organic fertilizer).

\section{ACKNOWLEDGEMENT}

The authors are extremely grateful to TraVinh Department of Science and Technology for providing funding to implement this topic. Thanks farmers from two districts: Tra $\mathrm{Cu}$ and CauNgang for their support sites for experiments. Thanks are due to HATRI and our colleagues in the Genetics and Plant Breeding Division for their support and valuable suggestions.

\section{REFERENCES}

[1] Aboelill A.A., Mehanna H.M., Kassab OM., \&Abdallah EF. 2012. The Response of Peanut to Foliar Spraying with Potassium Under Water Stress Conditions. Australian Journal of Basic and Applied Sciences, 6(8): 626-634.

[2] Aktar, M.W., Sengupta, D., Chowdhury, A., 2009. Impact of pesticides use in agriculture: their benefits and hazards. Interdiscip. Toxicol. 2 (1), 1-12.

[3] Brandenburg R.L., Jordan D.L., Royals B.R., Mahoney D.J. \& Johnson P.D. 2019. Utilization of Imidacloprid to Control Pests in Peanut in North Carolina. Peanut Science 46:1, 813. Online publication date: 24-Apr-2019.

[4] Basu M, Bhadoria PBS, Mahapatra SC. 2007. Comparative effectiveness of different organic and industrial wastes on peanut: Plant growth, yield, oil content, protein content, mineral composition and hydration coefficient of kernels, Archives of Agronomy and Soil Science 53(6), 645-658

[5] Camargo, O.A., Moniz, A.C., Jorge, J.A., Valadares, J.M. 2009. Métodos de análisequímica, mineralógica e física de solos do InstitutoAgronômico de Campinas. Rev. andupdated ed. InstitutoAgronômico de Campinas, Campinas, Boletimtécnico, 106. 77p.

[6] Costa, C., Garcia-Lestion, J., Costa, S., Coelho, P., Silva, S., Pingqarilho, M.,Valdiqlesias, V., Mattei, F., Dali Armi, V., Bonassi, S., Laffon, B., Snawder, J.,Teixeira, J.P., 2014. Is organic farming safer to farmers' health? A comparison between organic and traditional farming. Toxicol. Lett. 230, 166-176.

[7] Farag IAA, Zahran AA. 2014. Groundnut (Arachishypogaea L.) growth and yield responses to seed irradiation and mineral fertilization. Journal of Agriculture and Veterinary Science 7(15), p 63-70.

[8] Ferella, F., Cucchiella, F., D’Adamo, I., Gallucci, K., 2019. A techno-economic assessment of biogas upgrading in a developed market. J. Clean. Prod. 210, 945-957.

[9] Helen LG, Gerry G (2006). A handbook of preparations, techniques and organic amendments inspired by nature farming and adapted to locally available materials and needs in the western visayas region of the Philippines. Nature farming manure pp. 1-137. 
[10] Higa T (1996). Effective microorganisms - Their role in Kyusei Nature Farming. Proceedings of the 3rd International Nature Farming Conference. USDA; Washington pp. 20-23

[11] Janny GM, Vos, Ritchie BJ, Flood J (2003). The discovery of cocoa, a guide for training facilitators. CABI Biosciences $115 \mathrm{p}$.

[12] Jordan D.L., Brandenburg R., Brown B., Bullen G., Roberson G. \&Shew B., 2017. Peanut Information. North Carolina Cooperative Extension Service Pub. AG-331. 172 pages

[13] Katherine, K., Hendrik, W., 2010. Environmental Impacts of Agricultural Technologies.

[14] Evans School Policy Analysis \& Research (EPAR). EPAR Brief No. 65.

[15] Lalog J.T. 2011. Dynapharm Company Incorporation, Quezon City, Philippines

[16] Mungkunkamchao T., Kesmala T., Pimratch S., Toomsan B. \&Jothityangkoon D. 2013. Wood vinegar and fermented bioextracts: Natural products to enhance growth and yield of tomato. Sci. Hortic-Amsterdam. 154, 66-72.

[17] Narasimha G, Sumathi T, Janardhan A, Srilakhmi A, SaiGopal DVR (2012). Impact of indigenous microorganisms on soil microbial and enzyme activities. Archives of Applied Science Research 4(2):1065-1073.

[18] Onder, M., Ceyhan, E., Kahraman, A., 2011. Effects of agricultural practices on environment. international conference on biology. International Conference on Biology, Environment and Chemistry. IPCBEE 24, 28-32. Retrieved from. Http://ipcbee.com/vol24/6-ICBEC2011-C00015.

[19] Owens, K., Feldman, J., Kepner, J., 2010. Wide range of diseases linked to pesticides. Pestic. You 30, 13-21.

[20] Raij, Van B., Andrade, J.C., Cantarella, H., Quaggio, J.A. 2001. Análisequímica para avaliação da fertilidade de solos tropicais. InstitutoAgronômico, Fundação IAC, Campinas, $285 \mathrm{p}$

[21] Sharma, N., Singhvi, R., 2017. Effects of chemical fertilizers and pesticides on human health and environment: a review. Int. J. Agric. Environ. Biotechnol. 10 (6), 675679.

[22] Savci, S., 2012. An agricultural pollutant: chemical fertilizer. Inter. J. Environ. Sci. Dev. 3(1), 73-80.

[23] Subrahmanyam, P. and Hildebrand, G.L. 1997. Responses of peanut genotypes to fungicidal control of early leaf spot in Malawi. Peanut Sci. 24:73-77.

[24] SAS Institute Inc. 2017. The MIXED procedure. SAS Institute Inc. Saxton, A. 1998. A macro for converting mean separation output to letter groupings in Proc Mixed. Proc. 23rd SAS Users Group Intl., SAS Institute, Cary, NC: $1243-$ 1246

[25] Tran ThiKhanh Tran, Le Hoang Phuong, N. T. Phuoc. Nguyen thi Lang .2021. Effect of fertilizer on nutritional status and yield of peanut on TraVinh. Journal and Rural Development No. 17. Pages 45-53. 2021

[26] Yuan Y, Chen H, Yuan W, Williams D, Walker JT, Shib W. 2017. Is biochar-manure co-compost a better solution for soil health improvement and $\mathrm{N} 2 \mathrm{O}$ emissions mitigation? Soil Biology and Biochemistry 113, p 14-25. 